DE DE GRUYTER OPEN
Research Article

(C) 2017 Rufus B. Akindola and Christopher O. Ehinomen. This is an open access article licensed under the Creative Commons Attribution-NonCommercial-NoDerivs License (http://creativecommons.org/licenses/by-nc-nd/3.0/).

\title{
Military Incursion, Tribalism and Poor Governance: The Consequences for Development in Nigeria
}

\author{
Dr. Rufus B. Akindola \\ Department of Sociology \\ Federal University Oye-Ekiti, Ekiti State, Nigeria \\ Dr. Christopher O. Ehinomen \\ Department of Economics and Development Studies, \\ Federal University, Oye - Ekiti, Ekiti State, Nigeria
}

Doi: $10.1515 / \mathrm{mjss}-2017-0033$

\begin{abstract}
Nigeria continues to face difficult challenges as a country comprising many ethnic groups with different socio-cultural, religious and economic backgrounds. This paper critically reviewed literature and found that these challenges have shaped Nigeria's leadership and created unhealthy rivalry including, in particular, a deep sense of exploitation, marginalisation and oppression among certain ethnic groups. Despite Nigeria's abundant natural resources, the early politicians became self-centred and failed to make good use of these resources to improve the well-being of poor Nigerians, especially those in the rural areas. Instead, it was found that the politicians were engaged in economic vandalism and political opportunism, which precipitated a premature military takeover of government.
\end{abstract}

Keywords: Tribalism, Poverty, Corruption, Ethnicity, Nigeria, Independence

\section{Introduction}

The name "Nigeria" was coined by Flora Shaw, who later became the wife of Lord Lugard, the British colonial administrator, on 8 January 1897 (Meek, 1960 in George et al, 2012). It was then called Niger-area, but after a long usage it was shortened to Nigeria (George et al, 2012). The country is located in West Africa, bounded in the north by the republics of Niger and Chad, on the east by the Cameroon Republic, on the south by the Atlantic Ocean, and on the west by the Benin Republic (Nwachuku and Uzoigwe, 2004). There are over 250 nationalities in Nigeria. In this case, about 250 languages are spoken in the country, although some studies allude to 400 languages (Ajulo, 1990, Adegbija, 2000 in George et al, 2012). While there are contradictory population figures, Nigeria remains the most populous country in Africa with an ethnically and religiously volatile population of 173 million people (World Bank, 2015). The country is blessed with various mineral resources, including agricultural resources that comprise over 80 million hectares of arable land for forestry and crop cultivation (New Democratic Nigeria, 2004). However, the most important economic resource of the country is crude oil, which is produced in the Forest Zone. Nigeria ranks as Africa's largest producer of oil and the sixth largest oil producing country in the world which accounts for about 90 per cent of the country's total foreign earnings (NNPC, 2016). This suggests that Nigeria is rich in terms of its natural resources. Despite this, a substantial portion of its population lives in abject poverty. According to OPEC (2004), Nigeria's GDP per capita is USD549 compared to other oil producing developing countries such as Indonesia and Venezuela with USD1, 
187 and USD4, 050 respectively.

\section{Methodology}

An extensive and critical review of literature was conducted to meet the data requirements of the study. In particular, the review focused on text books, academic journal articles, past studies and government's publications.

\section{Nigeria's Transition from Colonisation to Political Independence}

As briefly reflected in the introduction above, the British created Nigeria in 1914 as a modern political entity. This, according to Falola (1999), was part of European partition of Africa that began in the last quarter of the nineteenth century. Like most sub-Saharan nations, Nigeria carries the burden of a difficult history (Unegbu, 2003). Political historians believe that Nigeria was an artificial creation given the complex diversity in religion, ethnicity and politics. Unegbu (2003), for example, explains that the diverse peoples who make up the present-day Nigeria were brought together in one country not from any desire on their part for a union, but solely by the will, and for the administrative convenience, of their colonial masters. Others like Tyler (2006) believe Nigeria was meant to serve British economic interests. Nevertheless, the British administrative strategy, which saw Nigeria divided into three zones, made it easy to rule through an indirect rule system and existing political institutions.

According to Unegbu (2003), the dominant ethnic group in the north is the Hausa-Fulani, most of who are Muslim and predominantly farmers. Unegbu further argues that the Yoruba people are predominant in the south-west with about half Christian and half Muslim, while the predominantly Catholic Igbo are the largest ethnic group in the south-east. A major implication of grouping the major ethnic groups, as noted earlier, has been that politically unrelated and diverse populations were brought together and forced to coexist. Despite the fact that the majority of the country's population is black, history has proven that in terms of ideology and principles, the different groups do not relate to one another (Falola, 1999). This poses serious implications for leadership and national development as cohesion is often elusive.

The major differences among the ethnic groups are also the focus of New African Yearbook (1994). It argues that the result of the British experiment was that at independence, Nigeria was effectively three nations, politically and economically. Not surprisingly, there has always been the fear of one group's domination over another, and this has remained a threat to the unity of Nigeria to date. For example, because of its size and numerical superiority, the northern region, which is populated by the Hausa-Fulani, tends to occupy a position of political dominance that enables it to benefit from the flow of oil revenue, which do not originate in that region (Tyler, 2006, Rubin et al., 1998). The domination appears to create a sense of marginalisation, oppression and exploitation among the remaining ethnic groups. This precipitated the assertion made by Herbst (1996) that the complex ethnic divisions of the country, coupled with religious polarisation between Muslims and Christians has meant that, from independence, Nigerian governments have had to engage in balancing acts aimed at allaying fears of ethnic domination and religious expansionism. The underpinning lies in the fact that, whoever holds the presidency usually faces a dilemma: either let the country break up, or use violence to hold it together (Tyler, 2006). This also has major implications for social and economic planning for the country. For example, instead of concentrating on policies that address the provision of basic services and infrastructure, governments have been preoccupied with how to deal with ethnic and religious tension.

In 1959, however, Federal elections were held which culminated in independence on October 1, 1960. As at this date, Nigeria was thought to be destined for prosperity, politically and economically. But the hopes that attended the independence rapidly evaporated as Nigeria's political and economic fortunes began to decline (Nwachukwu and Uzoigwe, 2004). A major factor was the nature of politics in the years 1960-1966 which were intricate and complex. According to New African Yearbook (1994), competition for political office was fierce and ruthless since control of the state apparatus was the only means of acquiring economic power. Further, the competition led 
to total corruption that pervaded public life because the elite's ambition was to acquire wealth by any means possible. The lack of concern for the interests of the poor resulted in serious social inequality (New African Yearbook, 1994). There were those who were relatively well-off because of their access to important resources and those who could not benefit from growth because they lacked the resources to improve their productive assets. It is not surprising that Adewale (2004) postulated that the rural people were mostly affected, as there was limited access to basic services, such as health care, safe drinking water and education.

The corrupt practices of the early politicians led to the first military takeover of government in 1966. Interestingly and according to Osoba (1996) in George et al (2012), this first military coup appeared to set the agenda of military rule in Nigeria as a corrective form of governance against corruption and indiscipline and in favour of restoration of democracy and justice. As expected, the intervention was greeted with jubilation because most Nigerians saw it as a major relief from corruption and nepotism. For example, the United Labor Congress welcomed the coup by asserting that it would aid the struggle of all true patriots against economic and social injustice, political fraud, tribalism and nepotism (Nwachuku and Uzoigwe, 2004). However, the army, which later became a major political player, was far from being the saviour Nigerians had hoped for. Its intervention in politics led to a bloody civil war between 1967 and 1970 and was instrumental to Nigeria's socioeconomic crisis (New African Yearbook, 1994). In the 56 years of Nigeria's independence, approximately 30 years of this have been under military dictatorships, which were characterised by lack of accountability and anti-democratic orientation (Falola, 1999; Nwagwu, 2002). Succinctly stated, Ojo (2009) observed that the Nigerian Army has struck on the following occasions: January 1966, July1966, July 1975, February 1976, December 1983, August 1985, April 1990, and November 1993 respectively. This, in effect, led to the collapse of the national economy as foreign investors closed their factories and offices and relocated to politically stable environments (Nwagwu, 2002). In fact, the poorly managed economy contributed to the high unemployment levels in the country to the extent that people with higher educational qualifications could not access gainful employment opportunities.

It is crystal clear, as Ehwarieme (2011) argues that the Nigerian civil war and the military's successful prosecution of that thirty-month war contributed to the military's sense of self-importance and provided the avenue for officers and men to interact more with the rest of society. This was done in ways that reduced the social distance between them and encouraged social and political alliances and networks that set the stage for coup making and wide acceptability of the resultant military regimes (Ehwarieme, 2011). In addition, the author explains that by successfully prosecuting the war to "keep Nigeria one," the military came to see itself as the symbol of national unity and felt justified to intervene when electoral politics became violent and fractious. Accordingly, the military's stay in power exposed them to the pleasures of political power and opportunities for primitive capital accumulation (Nwachukwu and Uzoigwe, 2004).

\section{The Structure of Nigeria}

It is imperative to state that Nigeria operates a federal system of government with a 36-state structure and a federal capital territory. While English is the official language, and is especially spoken amongst the intellectuals and educated population, as earlier indicated, there are many other ethnic dialects spoken by the majority of Nigerians (Ikpuk, 1995). In 1999, a new constitution was adopted and a peaceful transition to a democratically elected government was completed (World Bank, 2015). The new government embarked on economic reforms and also declared war on corruption. It is noteworthy that Nigeria has passed through complicated political periods. However, mismanagement of available resources through corrupt practices created and perpetuated poverty. Moreover, exploitation of ethnic and religious differences by Nigerian leaders contributed significantly to Nigeria's failure. This makes national unity difficult to achieve as most of Nigeria's political agendas are formulated along tribal lines (Umoren, 1996). 


\section{Economic Overview of Nigeria}

An analysis of the structure of the economy is a necessary precondition for understanding the genesis of poverty in Nigeria. In 1994, however, Jostein Gaarder stated in the African Business Magazine as follows:

"An egg has the potentiality to become a chicken, but this does not mean that all chicken's eggs become chickens - many of them end up on the breakfast table as fried eggs, omelettes, or scrambled eggs, without ever having realised their potentiality" (p.34).

The above quote describes Nigeria's potential to achieve sustainable economic growth and development, especially given its rich and diversified resource base. However, Nigeria has been known to lack the ability to manage its available resources to overcome its lingering problems. This is evident in its economy, which, according to Ayiuche, 2000), has manifested a diversity of serious malfunctions such as a high degree of inflation, scarcity of essential and basic commodities and unemployment. The failure of past and present leaders to manage the country's wealth effectively and efficiently, and the obsession with oil, which diverted attention away from the rest of the economy, has been the major problem with the economy (Ayiuche, 2000, Nwachukwu and Uzoigwe, 2004).

Before the discovery of oil in the country, the basis of the national economy was mainly agrarian (Ali-Akpajiak and Pyke, 2006). At the time, most Nigerians were traditional farmers who, as Fadayomi (1988) explains, had access to land where they grew a variety of products with the use of traditional implements. Such products, which included cotton, cocoa, rubber, rice and palm oil, as Fadayomi further argues, were grown for both domestic consumption and for export. The emphasis was, therefore, not on food imports since the majority of the people were food sufficient. Nigeria effectively became a major exporter of agricultural commodities and also the second largest producer of cocoa in the global market (Falola and Olanrewaju, 1992). As the authors put it, agriculture was contributing nearly 60 per cent of the Gross Domestic Product (GDP) and more than 70 per cent of foreign exchange earnings, including employment, for over 70 per cent of the country's total labour force. This shows how agriculture contributed to the nation's foreign earnings and, importantly, to the development of the rural economy.

In spite of its contributions to the economy, successive governments failed to plough back some of the income derived from agriculture into the provision of basic infrastructure that support economic and social activities in rural areas. Moreover, one of the immediate priorities of the government was to transform the industrial base of the economy in order to diversify away from the traditional agrarian economy (Ali-Akpajiak and Pyke, 2006). In this case, the post-independence industrialisation was financed largely by export taxes through the operation of the marketing boards (Fadayomi, 1988). The mining industry, which was characterised by an undue reliance on oil exportation in the 1970s, became dominant thereby demonstrating the rising significance of other sectors as the share of agricultural products in total exports plummeted from over 70 per cent in 1960 to less than 2 per cent in 1999 (Africa Recovery, 1999).

Falola and Olanrewaju (1992) contend that the oil boom marked the beginning of an unprecedented turnaround in the nation's economy as spending on major development increased precipitously and heavy demand for construction labour encouraged migration of farm workers to towns and cities. Nigeria, once a major agricultural exporter and largely self-sufficient in food, according to the authors, became a net importer of agricultural commodities. Food became scarce, as small farmers, who previously were food sufficient, could no longer grow food due to lack of incentives (Fadayomi, 1988). Yet there was deterioration in rural infrastructure and farmers had no access to working capital. The discovery of oil was perceived as a major relief to the nation, not only because of its economic and social benefits, but also because of its importance to the government's pursuit of its development objectives (Falola and Olanrewaju, 1992). Among the eleven world leading members of the Organisation of the Petroleum Exporting Countries, the World Bank, 2015) shows Nigeria as the sixth largest oil exporter and during the last twenty-five years, as having earned more than USD 300 billion from oil exports. Nonetheless, there is widespread 
poverty in the country. An important development in 1982 was the decline in world oil prices. According to FOS (1996), the government considered this fall as temporary and continued borrowing from international creditors. Further rises in oil prices in subsequent years, however, resulted in growing foreign debt and increased poverty.

The misspending of oil revenues, which saw billions of dollars ending up in the personal accounts of politicians and the army, according to Okumadewa et al., 2002), laid the foundation for economic crises. This not only undermined Nigeria's development prospects and fuelled sharp rises in poverty, but also the prolonged years of military rule and the lack of a clear strategy to diversify the economy away from oil dependence, was a factor in the crisis (Okumadewa et al., 2002). If much of the natural resources were tapped resourcefully alongside oil production, Nigeria would have done well economically and socially (Umoren, 1996). After all, Ghana, Mauritania, Tanzania, and Uganda are examples of countries with civil order, political openness and sound economic management that have recorded improved economic performance and better outcomes for the poor (Mekay, 2002). This has not been the case in Nigeria because, as Okumadewa et al., (2002) further found in their study of III-being and insecurity in Nigeria, the sharp rises in poverty in the 1980s and 1990s were mostly fuelled by bad governance and political instability.

Access to basic infrastructure, arguably, is critical because it constitutes resources that are necessary for human development, which the UNDP (1997) defines as a "process of enlarging poor people's choices" (p.5). That is, creating the opportunity for people to effectively develop their potential. When people are not able to access these resources, then opportunities and choices most basic to human development are denied as are the opportunities to lead a long, healthy and creative life, and to enjoy a decent standard of living (UNDP, 1997). In addition, the UNDP suggests that individuals are denied the right to gain their own self-esteem, and the esteem of others in the society, due to serious limitations to their participation in social life. People with education, for example, have better chances of improving their health status while also increasing their earning potential, compared to those with little or no education whose opportunities and choices are limited. The ability of individuals to survive, therefore, depends on the availability of resources that can be used to improve their well-being in order to have improved life expectancy and reduced infant mortality.

Sen (1999) has consistently maintained that substantive freedoms are fundamental if individuals are to enjoy leading the kind of life they have reason to value. Sen's main argument is that what constitutes freedom includes not just money but also access to the means of achieving those things that individuals' desire. As noted earlier, adequate access to education and health care can provide the opportunity to meet other needs. The inability of individuals to access these essential services is the basis of Sen's conclusion that poverty must be seen as the deprivation of basic capabilities, rather than merely lowness of income. In other words, the well-being of individuals depends on certain levels of functioning. That is, how individuals can best achieve what they desire in life. For example, the ability of individuals to have good education that provides access to well remunerated employment opportunities, the ability to participate in the life of the society with dignity or the ability to appear in public and command respect, are such functionings (Sen, 1999).

\section{Conclusion}

This paper has demonstrated that Nigeria faces difficult challenges as a country comprising many ethnic groups with different socio-cultural, religious and economic backgrounds. These challenges have obviously shaped Nigeria's leadership and created unhealthy rivalry including, in particular, a deep sense of marginalisation and oppression among certain ethnic groups. Despite Nigeria's abundant resources, the early politicians, who were mostly self-centred, failed to make good use of these resources to improve the wellbeing of poor Nigerians, especially in rural areas. Instead, the politicians were engaged in economic vandalism and political opportunism, which led to a premature military takeover of government. It was also argued that the military did not perform better than the early politicians as they also encouraged and perpetrated corruption of the highest order. Although the discovery of abundant crude oil was regarded as a blessing for Nigeria, both 
politicians and the military abandoned agriculture, which was the mainstay of the country's economy, and concentrated mainly on oil export. Their inability to diversify the economy away from oil dependence led to serious economic crises when world oil prices began to fall. The rural sector was badly affected due to serious deterioration in basic services and infrastructure. This had serious impact on rural poor people who also could no longer benefit from agriculture.

\section{References}

Adewale, S. A. (2004): An Internet-Based Telemedicine in Nigera. International Journal of Information Management, 24(3): 21.

Adegbija, E. (2000): Saving Threatened Languages in Africa: ACase Study of Oko. In George, O. J., Amujo, O. C., Cornelius, N. (2012). Military Intervention in the Nigerian Politics and Its Impact on the Development of Managerial Elite: 1966-1979. Canadian Social Science 8 (6): 45-53.

Africa Recovery (1999): United Nations Publication, New York, 12(4):12-15.

Ajulo, S. (1990): Reflections on Sections 51 and 91 of the 1979 Constitution of the Federal Republic of Nigeria. In George, O. J., Amujo, O. C., Cornelius, N. (2012). Military Intervention in the Nigerian Politics and Its Impact on the Development of Managerial Elite: 1966-1979. Canadian Social Science 8 (6): 45-53.

Ali-Akpajiak, S. C. and Pyke, T. (2006): Measuring Poverty in Nigeria, Oxfam Working Papers online: www.oxfam.org.uk/what_we_do/resources/wp_poverty_nigeria.htm

Ayiuche, A.C. (2000): Problems of Development Planning and Implementation in Nigeria. Discovery and Innovation, 12 (1-2), 12-20.

Ehwarieme, W. (2011): The Military Factor in Nigeria's Democratic Stability, 1999-2009. Armed Forces \& Society 37(3): 494-511.

Fadayomi, T.O. (1988): Rural Poverty and Migration in Nigeria (The Impact of the Eastern Zone of Bauchi State Agricultural Development Project, Nigerian Institute of Social and Economic Research (NISER), Ibadan.

Falola, T, and Olanrewaju, S. A. (1992): Rural Development Problems in Nigeria, Avebury, Aldershot.

Falola, T. (1999): The History of Nigeria, Greenwood Press, Westport, London.

Federal Office of Statistics (FOS, 1996): Poverty \&Welfare in Nigeria. Policy Research Working Paper Series, The World Bank.

Gaarder, J. (1994): The Nigerian Economy- A Break from the Past. African Business, (236), 31-32.

Herbst, J. (1996): Is Nigeria a Viable State? The Washington Quarterly, 9 (2), 151-173.

Ikpuk, J. S. (1995): Militarisation of Politics and Neo-Colonialism: The Nigerian Experience, 1966-90. Janus Publishing Company.

Meek, C. (1960): The Niger and the Classics: The History of a Name. In George, O. J., Amujo, O. C., Cornelius, N. (2012). Military Intervention in the Nigerian Politics and Its

NNPC (2016): History of the Nigerian Petroleum Industry http://www.nnpcgroup.com/NNPCBusiness /BusinessInformation/OilGasinNigeria/IndustryHistory.aspx (Date visited: 16 May 2016).

Impact on the Development of Managerial Elite: 1966-1979. Canadian Social Science 8 (6): 45-53.

Mekay, E. (2002): World Bank: Critics See Troubling Poverty Trends, Global Information Network, New York, p.1.

New Democratic Nigeria: Agriculture (2004), Volume 5. An official publication of the Nigeria High Commission, London.

NewAfrican YEARBOOK: 52 African Countries 1993-1994 (1994), Ninth Edition An IC Publications, London.

Nwachukwu, L. A. and Uzoigwe, G. N. (2004): Troubled Journey: Nigeria Since the Civil War. University Press of America, New York.

Nwagwu, E. (2002): Taming the Tiger: Civil-Military Relations Reform and the Search for Political Stability in Nigeria. University Press of America, Maryland.

Ojo, E.O. (2009) Guarding the Guardians: A Prognosis of Panacea for Evolving Stable Civil Military Relations in Nigeria, Armed Forces \& Society 35 (4) : 693-703.

Okumadewa, F., Aina, O., Ayoola, G., Mamman, A., Nweze, N., Odebiyi, T., Shehu, D. and Zacha, J. (2002): Nigeria: III-Being and Insecurity. In Voices of the Poor: From Many Lands, Narayan, D. and Petesch, P. Oxford University Press, New York, pp85- 112.

Olanrewaju, S. A. and Falola, T. (1992): Rural Development Problems in Nigeria, Avebury, Aldershot.

Organisation of the Petroleum Exporting Countries (OPEC 2004). Member Countries: Facts and Figures.

Osoba, S. O. (1996): Corruption in Nigeria: Historical Perspectives. Review of African Political Economy. In George, O. J., Amujo, O. C., Cornelius, N. (2012). Military Intervention in the Nigerian Politics and Its Impact on the Development of Managerial Elite: 1966-1979. Canadian Social Science 8 (6): 45-53.

Rubin, B.R., Robinson, P. T. and Lewis, P. M. (1998): Stabilizing Nigeria: Sanctions, Incentives, and Support for Civil Society. The Century Foundation Press, New York.

Sen, A. (1999): Development as Freedom, Oxford University Press, New York. 
Tyler, J., (2006): Worse than Iraq? Nigeria's Presdient and one time hope for a stable future is leading his country towards impolsion- and possible U.S. military intervention. The Atlantic Monthly, 297(3):33-34.

Umoren, J. (1996): Democracy and Ethnic Diversity in Nigeria, University Press of America, Maryland.

UNDP (1997): 'Human Development Report 1997', United Nations Development Programme (UNDP), Oxford University Press, New York.

Unegbu, O. (2003): Nigeria: Bellwether of African Democracy. World Policy Journal, 20 (1), 41-48.

World Bank (2015): Overview of Nigeria. http://www.worldbank.org/en/country/nigeria/overview (Date visited: 16 May, 2016) 